\title{
Late defoliation of 'Chardonnay' grapevine in subtropical highland climate
}

\author{
Gabriel Machado de Figueiredo* (D), Renata Vieira da Mota (D), Claudia Rita de Souza (D), \\ Isabela Peregrino (D), Fernanda de Paula Fernandes (D), Murillo Albuquerque Rhegina (D) \\ Empresa de Pesquisa Agropecuária de Minas Gerais - Núcleo Tecnológico Uva e Vinho - Caldas (MG), Brazil.
}

\begin{abstract}
Chardonnay cultivar has shown great potential of planting and development in sites above $900 \mathrm{~m}$ of Brazilian southeast for sparkling wines production. The quality of this product is related to vineyard climate and management, since both affect the vine development and grape composition. In this study, three defoliation orientations (east, west and east/west face), at veraison, and a group without defoliation, were compared in order to observe the impacts of this management on the productivity, grape and base wine quality. Yield, grape components, must and base wine composition were analyzed for two years. East/west defoliation increased alcohol content and decreased acidity in base wines, while the group without defoliation increased acidity, according to the higher and lower sun exposure, respectively. Defoliation at veraison increased the incidence of bunch rots. Differences in the aromatic composition of the base wines between the harvests were identified. The east/west defoliation treatment presented more intense fruity, citrus and tropical aromas. For regions characterized by subtropical highland climate ( $\mathrm{Cwb}$ ) in the Brazilian Southeast, late defoliation is not recommended since defoliated plants were more susceptible to fungus infection at flowering and berry formation.
\end{abstract}

Key words: Vitis vinifera, aroma, bunch rot, sparkling wine, vitiviniculture.
Received:

Sep. 2, 2019

Accepted:

Dec. 17, 2019

Section Editor:

Cláudia Sales Marinho

*Correspondence author: gmdfigueiredo@gmail.com

\section{INTRODUCTION}

Vines are very demanding in farming practices when compared to other fruit plants. Defoliation is a common management in the vegetative canopy of plants at any time, from the beginning of flowering until the fruit ripens (Leão et al. 2016; Würz et al. 2017), improving canopy microclimate by providing higher temperatures, solar radiation and aeration on fruits.

This management can improve grape quality, reducing problems caused by high precipitation and high air humidity during ripening (Hed et al. 2015). However, overexposure of bunches to light intensities and high temperatures, especially in hot climates, can reduce the berry color (Leão et al. 2016) and decrease excessively the acidity (Baiano et al. 2015). Leaf removal is also an effective technique for improving wine quality and providing positive effects on the sensory profile, favoring the concentration of aromatic compounds, increase of anthocyanins and phenolics (Baiano et al. 2015; Alessandrini et al. 2017). Defoliation provides wine with better sensory profile, less astringent and less alcoholic (Tessarin et al. 2014) and can modify the organoleptic properties of wines with citrus, floral and spicy notes (Alessandrini et al. 2017). 
According to Manfroi et al. (1997) and Pötter et al. (2010), microclimate management of vegetative canopy in traditional wine-producing countries from Old and New World is an effective way to increase wine quality. It is also effective in controlling bunch rot, since defoliation can reduce the amount of fungicide applications (Hed et al. 2015).

There is a consensus among studies that climatic conditions, genotype and phenological stage will influence the effects of defoliation. Therefore, this work proposes to evaluate the impacts of defoliation applied in different orientations of vines in relation to sun exposure (east, west and east/west) performed at the phenological stage of veraison on the quality of the grapes and wine of Chardonnay cultivar.

\section{MATERIAL AND METHODS}

\section{Plant material and experimental design}

The experiment was conducted in a commercial vineyard located in the city of Caldas $\left(21^{\circ} 55^{\prime} \mathrm{S}\right.$ and $46^{\circ} 23^{\prime} \mathrm{W}, 1,300 \mathrm{~m}$ hight), in the southern part of the state of Minas Gerais, Brazil. The region is characterized by subtropical highland climate $(\mathrm{Cwb})$, with average annual rainfall of $1,600 \mathrm{~mm}$, with highest volumes accumulated between October and March. The average temperature in this period is $20.4^{\circ} \mathrm{C}$ with thermal amplitude of $10.7^{\circ} \mathrm{C}$. Figure 1 illustrates rainfall distribution during pre-flowering to harvest.

Vines were trained in a vertical shoot positioning trellis system, with bilateral cordon and double spur pruned at August 10, 2016 and August 5, 2017 in both seasons. The vine density had row spacing of $2.5 \mathrm{~m}$ and distance between plants of $1.0 \mathrm{~m}$, resulting in 4,000 plants per hectare, and North-South planting direction.

The experiment started in 2016 with seven-years-old cultivar Chardonnay clone 76 -ENTAV-INRA grafted onto 1103 Paulsen, commonly used in subtropical climates. Defoliation treatments were applied at veraison (November 29, 2016 and November 27, 2017) at the east, west or east/west sites of the vines. The control consisted of plants without defoliation. All cultural practices were applied equally for all treatments, in accordance with standard commercial practices for Chardonnay cultivar. The experimental design was completely randomized with six replications for each treatment, represented by six plants per plot, totaling an experimental area of 144 plants.

Defoliation was intensively performed between the first and second wires at veraison, in order to expose the bunches.

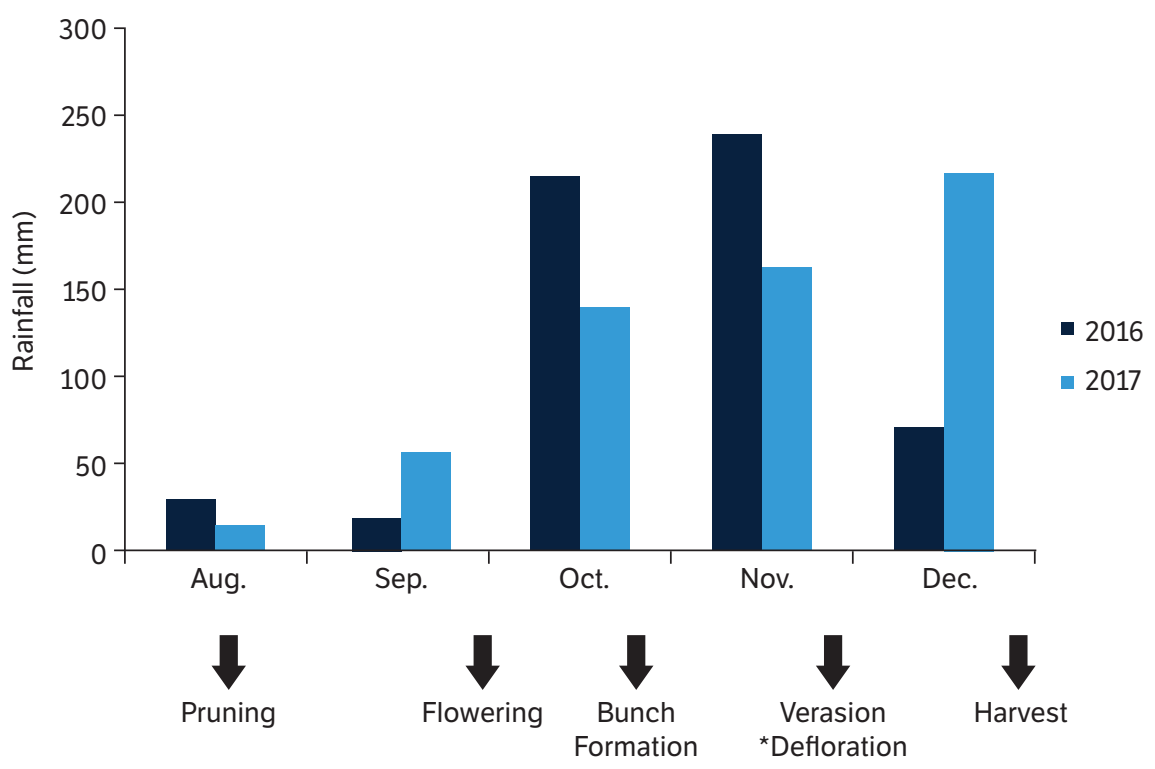

Figure 1. Rainfall distribution from pruning to harvest of 'Chardonnay' berries in 2016 and 2017 seasons. 


\section{Agronomical and physicochemical analyses}

Berry temperatures were measured by piercing eight berries per plot (four berries facing east and four berries facing west) using a portable digital thermometer on sunny days on December 15, 2016 and December 13, 2017. Five measurements were taken throughout the day at three-hour intervals starting at $7 \mathrm{am}$.

Harvesting was performed at the four central plants per plot, on December 29, 2016 and December 28, 2017. Bunches average weight was estimated by the ratio between the average yield per plant and the number of bunches. Average weight of 100 berries per plot was determined. Yield per hectare was estimated by the average yield per plant and total plants per hectare (Mendonça et al. 2016).

In 2016, bunches rot was evaluated without differentiation by types. In 2017, due to the higher rot bunches incidence, Botrytis cinerea and Glomerella cingulata symptoms were quantified separately. One hundred bunches were evaluated by treatment, and they were rated from 1 to 9 according to infection severity (EMBRAPA/CNPUV s.d.).

Must samples were analyzed for $\mathrm{pH}$, titratable acidity (TA) and soluble solids ( $\left.{ }^{\circ} \mathrm{Brix}\right)$, using a digital potentiometer (Micronal, B472), titration with $0.1 \mathrm{~N} \mathrm{NaOH}$ with phenolphthalein as an indicator and a portable digital refractometer (ATAGO Pal 1) were respectively used.

\section{Winemaking and physicochemical quality of wine}

After harvest, the grapes were stored in a cool chamber for $24 \mathrm{~h}$ at $4{ }^{\circ} \mathrm{C}$. For each treatment, $30 \mathrm{~kg}$ of grapes were destemmed by hand and thereafter crushed. Must was separated from the solid parts and placed in a 13.25 L Pirex glass carboy, then $2 \mathrm{~g}$ per hectoliter of pectolitic enzyme COAPECT VRC and $100 \mathrm{mg} \mathrm{SO} \cdot \mathrm{kg}^{-1}$ were added for all must samples. Cold settled occurred at $10^{\circ} \mathrm{C}$ for $48 \mathrm{~h}$, following by the racking for a glass carboy with the same volume. Clear must was inoculated with Saccharomyces cerevisiae bayanus rehydrated wine yeast and added with $20 \mathrm{~g} \cdot \mathrm{hL}^{-1}$ of fermentation activator. Density was measured daily during alcoholic fermentation at $17^{\circ} \mathrm{C}$. When density reached constantly $990 \mathrm{~g} \cdot \mathrm{L}^{-1}$ and the residual sugars were below $3 \mathrm{~g} \cdot \mathrm{L}^{-1}$, the wine was racked to remove lees and added with $50 \mathrm{mg} \cdot \mathrm{L}^{-1}$ potassium metabisulfite and $80 \mathrm{~g} \cdot \mathrm{hL}^{-1}$ of bentonite. Wines stayed 12 days in cold stabilization at $-2{ }^{\circ} \mathrm{C}$ and then racked to remove the clarification lees, still not limpid, more $30 \mathrm{~g} \cdot \mathrm{hL}^{-1}$ of bentonite was added followed by 12 days of clarification.

Total acidity (g. $\mathrm{L}^{-1}$ tartaric acid), $\mathrm{pH}$, alcohol (\%), crude extract $\left(\mathrm{g} \cdot \mathrm{L}^{-1}\right)$ and residual sugars $\left(\mathrm{g} \cdot \mathrm{L}^{-1}\right)$ analyses were performed after the final clarification in order to detect if the wine was within standards of the Brazilian law (Amerine and Ough 1980).

For the isolation and concentration of volatiles, the headspace solid-phase microextraction technique (HS-SPME) was used in accordance with Gürbüz et al. (2006), with some modifications. All extractions were carried out using a DVB/CAR/PDMS fiber of 50/30 $\mu \mathrm{m}$ film thickness (Supelco, Bellefonte, PA, USA). An aliquot of $10 \mathrm{~g}$ of wine was placed in $20 \mathrm{~mL}$ vials closed with Teflon cap. Vials were heated to $30{ }^{\circ} \mathrm{C}$ under agitation with a magnetic stir bar for $10 \mathrm{~min}$ for headspace equilibrium. Adsorption time was $45 \mathrm{~min}$ at the same temperature. The SPME fiber was then directly injected into a gas chromatograph mass spectrometer (Agilent Technologies Inc., Santa Clara, USA) operated with ChemStation software. The SPME fiber was held for $10 \mathrm{~min}$ at $250^{\circ} \mathrm{C}$ for desorption of volatile compounds which were separated using a capillary column HP-5MS $(30 \mathrm{~m} \times 0.25 \mathrm{~mm} \times 0.25 \mu \mathrm{m})$ with helium as carrier gas at constant flow of $1 \mathrm{~mL} \cdot \mathrm{min}^{-1}$. Initial oven temperature was $40{ }^{\circ} \mathrm{C}$ held for $5 \mathrm{~min}$, then increased to $160{ }^{\circ} \mathrm{C}$ at $3{ }^{\circ} \mathrm{C} \cdot \mathrm{min}^{-1}$ and to $250{ }^{\circ} \mathrm{C}$ at $10^{\circ} \mathrm{C} \cdot \mathrm{min}^{-1}$ and hold for $10 \mathrm{~min}$ before return to $40^{\circ} \mathrm{C}$, in a total cycle of $64 \mathrm{~min}$; transfer line temperature at $250^{\circ} \mathrm{C}$; MS detector in SCAN mode $30-500 \mathrm{~m} / \mathrm{z}$.

Volatile compounds were identified by comparison with the NIST library (NIST 11, version 2.0, Gaithersburg, USA) considering $70 \%$ similarity as the cut-off, further confirming the results with the retention indexes calculated according to Kovats index (Ettre 2003). Only aromatic compounds with difference in Kovats retention indices lower than 50 units up or down were accepted. Furthermore, only compounds described in the literature as aromatic were considered (Burdock 2010) and separated by classes according to Ilc et al. (2016). All analyses were carried out in triplicate. 
With the exception of the volatile compound profile data of the base wines, all data were tested by analysis of variance (ANOVA), with one factor (defoliation orientations). The treatments mean values were compared by Scott-Knott test at $5 \%$ significance level. Profiles in volatile compounds of base wines were evaluated using the principal components analysis (PCA), by the program MetaboAnalyst 4.0 (Xia 2015), with the data normalized by median, treated in the logarithmic scale and scaled according to the range scale.

\section{RESULTS AND DISCUSSION}

\section{Production}

No significant differences in production parameters were observed between treatments and control group without defoliation in any of the evaluated harvests. Productivity declined in 2017, possibly due to crop biannuality (Table 1).

Higher quality fruits are expected with leaf removal, but lower plant yield. However, the present study showed that late defoliation does not affect grapevine yield rates. Alessandrini et al. (2017) observed that early defoliated vines, in flowering stage, produce fewer bunches and fewer berries per bunches, but this favors the beneficial compounds accumulation in the fruit, while late defoliated vines, at veraison or ripening stage, are not affected by this practice. However, defoliation, from flowering to veraison, can decrease vineyard yield and increase grape quality on Tempranillo and Graciano cultivars (Diago et al. 2010). Therefore, defoliation effects are more related to the phenological phase when it occurs, the vineyard environmental characteristics and the cultivars.

\section{Bunch sanity}

In this study, there was a significant increase of bunch rot from the first to the second year (Tables 2 and 3 ).

Table 1. Number of bunches per plant, bunch weight, 100 berry weight and yield of Chardonnay cultivar submitted to different late defoliation orientation.

\begin{tabular}{|c|c|c|c|c|}
\hline \multirow{3}{*}{ Harvest Year } & \multicolumn{4}{|c|}{ DEFOLIATION } \\
\hline & Control & East & West & East/West \\
\hline & \multicolumn{4}{|c|}{ Yield/Plant (kg.plant ${ }^{-1}$ ) } \\
\hline 2016 & $3.09 a$ & $2.98 \mathrm{a}$ & $2.97 \mathrm{a}$ & $3.15 \mathrm{a}$ \\
\hline \multirow[t]{2}{*}{2017} & $2.54 \mathrm{a}$ & $2.36 \mathrm{a}$ & $2.43 a$ & $2.08 \mathrm{a}$ \\
\hline & \multicolumn{4}{|c|}{ Number of bunches } \\
\hline 2016 & $27 a$ & $27 a$ & $27 a$ & $24 a$ \\
\hline \multirow[t]{2}{*}{2017} & $27 a$ & $27 a$ & $26 a$ & $24 a$ \\
\hline & \multicolumn{4}{|c|}{ Bunch weight (g) } \\
\hline 2016 & $114.37 \mathrm{~b}$ & $110.19 \mathrm{~b}$ & $109.85 \mathrm{~b}$ & $131.38 \mathrm{a}$ \\
\hline \multirow[t]{2}{*}{2017} & 95.09 a & $88.58 a$ & $92.93 \mathrm{a}$ & 87.49 a \\
\hline & \multicolumn{4}{|c|}{100 berry weight (g) } \\
\hline 2016 & $1.91 \mathrm{a}$ & $1.87 \mathrm{a}$ & $1.99 \mathrm{a}$ & $1.90 \mathrm{a}$ \\
\hline \multirow[t]{2}{*}{2017} & $1.85 \mathrm{a}$ & $1.83 \mathrm{a}$ & $1.82 \mathrm{a}$ & $1.85 \mathrm{a}$ \\
\hline & \multicolumn{4}{|c|}{ Yield $\left(t \cdot h^{-1}\right)$} \\
\hline 2016 & $12.35 \mathrm{a}$ & $11.90 \mathrm{a}$ & $11.86 \mathrm{a}$ & $12.61 \mathrm{a}$ \\
\hline 2017 & $10.17 \mathrm{a}$ & $9.44 a$ & $9.73 \mathrm{a}$ & $8.33 \mathrm{a}$ \\
\hline
\end{tabular}

Averages followed by same letter in same line were not significantly different at $5 \%$ of probability by Scott-Knott test. 
Table 2. Bunch rot incidence on 'Chardonnay' submitted to different late defoliation orientation, 2016 season.

\begin{tabular}{|c|c|c|c|c|c|}
\hline Defoliation & S1 & S3 & S5 & S7 & S9 \\
\hline Control & $82 b$ & $12 a$ & $3 a$ & $1 a$ & $0 a$ \\
\hline East & $70 a$ & $22 b$ & $6 a$ & $\mathrm{Oa}$ & $0 \mathrm{a}$ \\
\hline West & $70 a$ & $17 \mathrm{~b}$ & $3 a$ & $7 b$ & $0 \mathrm{a}$ \\
\hline East/West & $70 a$ & $21 b$ & $6 a$ & $0 \mathrm{a}$ & $0 \mathrm{a}$ \\
\hline
\end{tabular}

Legend: S1 = no infection, S3 = light infection, S5 = medium infection, S7 = strong infection and S9= very strong infection. Averages followed by same letter in same column were not significantly different at $5 \%$ of probability by Scott-Knott test.

Table 3. Bunch rot incidence on 'Chardonnay' submitted to different late defoliation orientation, 2017 season.

\begin{tabular}{cccccccccc}
\hline Defoliation & S1 & S3 G & S5 G & S7 G & S9 G & S3 B & S5 B & S7 B & S9 B \\
\hline Control & $40.5 \mathrm{c}$ & $24 \mathrm{a}$ & $7 \mathrm{a}$ & $4 \mathrm{a}$ & $3 \mathrm{a}$ & $4 \mathrm{a}$ & $1.5 \mathrm{a}$ & $1.5 \mathrm{a}$ & $5 \mathrm{~b}$ \\
\hline East & $33.5 \mathrm{~b}$ & $25 \mathrm{a}$ & $11 \mathrm{~b}$ & $5 \mathrm{a}$ & $4 \mathrm{a}$ & $3 \mathrm{a}$ & $2 \mathrm{a}$ & $2 \mathrm{a}$ & $1 \mathrm{a}$ \\
\hline West & $33 \mathrm{~b}$ & $25.5 \mathrm{a}$ & $12 \mathrm{~b}$ & $4.5 \mathrm{a}$ & $6 \mathrm{a}$ & $2.5 \mathrm{a}$ & $1.5 \mathrm{a}$ & $1.5 \mathrm{a}$ & $1.5 \mathrm{a}$ \\
\hline East/West & $25 \mathrm{a}$ & $21.5 \mathrm{a}$ & $15 \mathrm{~b}$ & $10 \mathrm{~b}$ & $11 \mathrm{~b}$ & $1 \mathrm{a}$ & $1.5 \mathrm{a}$ & $3 \mathrm{a}$ & $2 \mathrm{a}$ \\
\hline
\end{tabular}

Legend: $\mathrm{S} 1=$ no infection, $\mathrm{S} 3=$ light infection, $\mathrm{S} 5=$ medium infection, $\mathrm{S} 7=$ strong infection and $\mathrm{S} 9=$ very strong infection $-\mathrm{G}=$ Glomerella cingulata and $\mathrm{B}=\mathrm{B}$ otritys cinereal. Averages followed by same letter in same column were not significantly different at $5 \%$ of probability by Scott-Knott test.

The control without defoliation showed lower incidence of bunch rot in both years, however, in 2017 it showed a tendency to severe Botrytis cinerea infection. In the same year, Glomerella cingulata infection was significantly higher than Botrytis cinerea infection for all groups evaluated, being more severe in the east/west treatment.

High temperatures and high humidity are favorable conditions for bunch rot occurrence (Thomas et al. 1988). In the region where this study occurred, during the flowering and harvest months, average temperatures and rainfall indices are high (Fig. 1). During December 2017, rainfall was higher than the same period in 2016, coinciding with the critical phase of fungal infection, which occurs during the ripening, when there are higher sugar concentrations in the berries (Jackson 2008), which may have contributed to higher bunch rot incidence in 2017.

With late defoliation, performed at veraison, the canopy microclimate at flowering and berry formation was favorable to fungal colonization. Little aeration, reduction of solar radiation on bunches zone and excess leaves that impair fungicides dispersal (Hed et al. 2015) are favorable for fungal colonization, even without visible symptoms (McClellan and Hewitt 1973), indicating that the fungus infected before veraison and the atmospherical conditions were favorable for fungus growth at grape ripening period.

Late defoliation also increased berry temperature (Figs. 2 and 3) and exposed the infected bunches to direct rainfall, which favored the development of the pathogen (Thomas et al. 1988), justifying the higher Glomerella cingulata incidence in 2017, in the east/west treatment, which had higher intensity of defoliation.

Data on berry temperature and bunch rot incidence in 2017 show that higher temperatures during the ripening of defoliated treatments favored the development of Glomerella cingulata, while milder temperatures of the control were favorable to Botritys cinerea infection (Steel et al. 2011).

These results disagree with other studies that show defoliation as an efficient practice to control bunch rot (HernandezOrte et al. 2015; Alessandrini et al. 2017). However, they are explained by the late defoliation applied in this study, which has less impact on bunch rot control than early defoliation (performed on flowering) (Würz et al. 2017).

\section{Must composition}

In 2016 and 2017 seasons, the east/west treatment showed higher soluble solids content than the other treatments, while the control showed the lowest content in both years. A slight $\mathrm{pH}$ variation was observed among treatments, but not enough to change wine composition. The control showed higher total acidity in 2016 and maintained the trend in 2017, with higher 


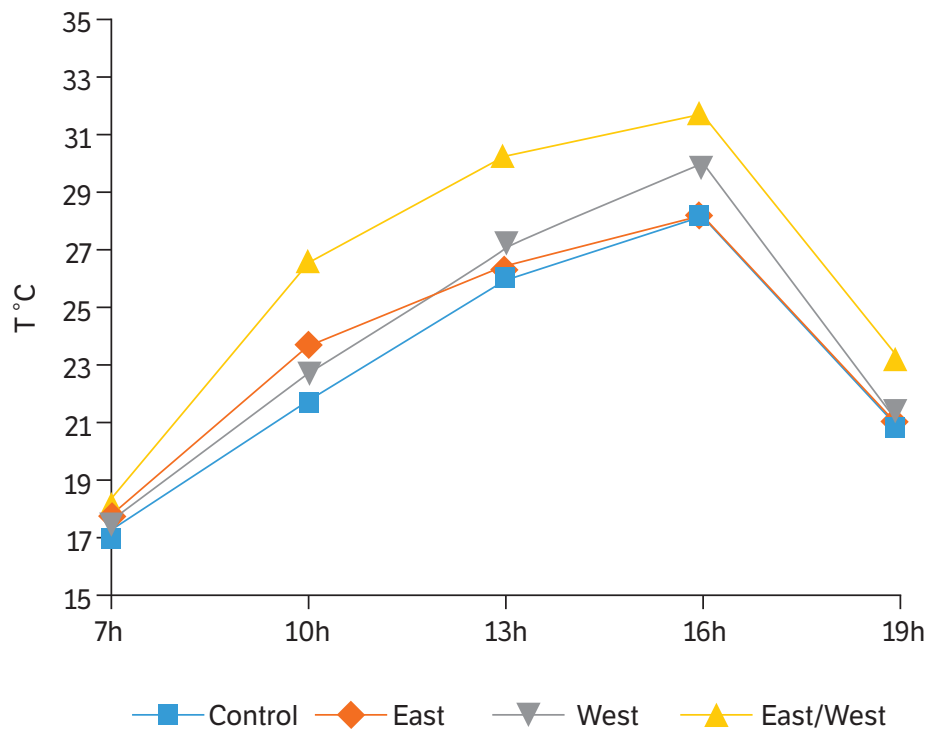

Figure 2. Evolution of daily berry temperatures of 'Chardonnay' vine submitted to different late defoliation orientation, 2016 season.

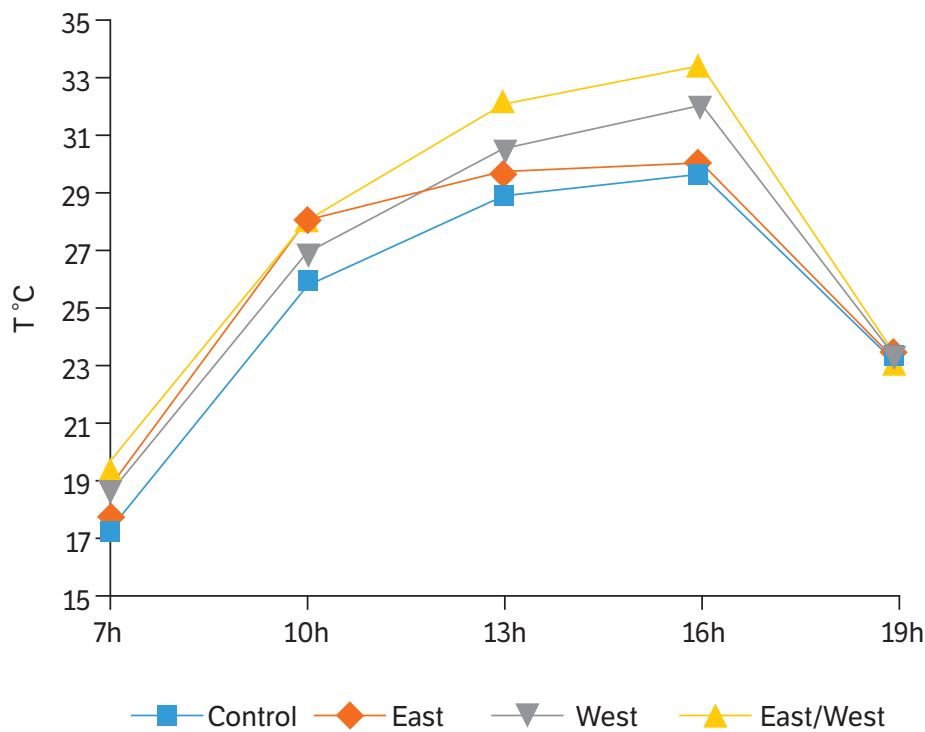

Figure 3. Evolution of daily berry temperatures of 'Chardonnay' vine submitted to different late defoliation orientation, 2017 season.

average than defoliation treatments. The largest reductions in total acidity were observed in the east/west treatment, but this did not affect sparkling wine quality, as acidity still remained high, similar to values observed in traditional producing regions (Rizzon et al. 2009) (Table 4). Higher acidity is beneficial to sparkling wines as it provides them more freshness (Mendonça et al. 2016).

Must composition reflects the influence of temperature on the acid and soluble solid concentration. In the control group, milder berry temperatures preserved acidity, while acid degradation was observed in defoliated treatments, which had higher berry temperatures. Regarding the soluble solids content, superior results were observed in the east/west treatment, with higher temperatures, opposing results of control group.

In studies with defoliation performed at different stages of bunch development, Baiano et al. (2015) noted that higher bunches exposure to solar radiation with consequent higher berry temperature increased the photoassimilate translocation 
Table 4. Soluble solids (SS), $\mathrm{pH}$ and total acidity (TA) in 'Chardonnay' must of grapevines submitted to different late defoliation orientation, 2016 and 2017 seasons.

\begin{tabular}{|c|c|c|c|c|}
\hline \multirow{3}{*}{ Harvest Year } & \multicolumn{4}{|c|}{ DEFOLIATION } \\
\hline & Control & East & West & East/West \\
\hline & \multicolumn{4}{|c|}{ SS ( ${ }^{\circ}$ Brix) } \\
\hline 2016 & $18.3 a$ & $18.7 b$ & $18.4 \mathrm{~b}$ & $19.0 \mathrm{c}$ \\
\hline \multirow[t]{2}{*}{2017} & $17.8 \mathrm{a}$ & $18.2 \mathrm{c}$ & $18.0 \mathrm{~b}$ & $18.3 \mathrm{~d}$ \\
\hline & \multicolumn{4}{|c|}{$\mathrm{pH}$} \\
\hline 2016 & $3.12 \mathrm{a}$ & $3.12 \mathrm{a}$ & $3.13 \mathrm{a}$ & $3.16 \mathrm{~b}$ \\
\hline \multirow[t]{2}{*}{2017} & $3.22 \mathrm{a}$ & $3.22 \mathrm{~b}$ & $3.18 \mathrm{~b}$ & $3.24 c$ \\
\hline & \multicolumn{4}{|c|}{$\mathrm{TA}\left(\mathrm{meq} \cdot \mathrm{L}^{-1}\right)$} \\
\hline 2016 & $144.33 \mathrm{~d}$ & $133.00 \mathrm{~b}$ & $138.67 \mathrm{c}$ & 129.33 a \\
\hline 2017 & $158.67 \mathrm{c}$ & $150.67 b$ & $156.67 \mathrm{c}$ & $141.33 \mathrm{a}$ \\
\hline
\end{tabular}

Averages followed by same letter in same line were not significantly different at $5 \%$ of probability by Scott-Knott test.

rate and sugar concentration in the berry. On the other hand, Zoecklein et al. (1992) argue that defoliation causes a reduction in sugar content and attribute this fact to the removal of photosynthetically active leaves and the incomplete ripening of the bunches caused by the reduction of leaf area (Zoecklein et al. 1992). Different results are explained by the genotype, environmental conditions, soil type and management influence on the sugar concentration and other grapes substances (Van Leeuwen et al. 2004). In this study, late defoliation increased soluble solids content and decreased total acidity.

For the production of quality sparkling wine, the grapes must be yield with relatively low $\mathrm{pH}$ (3.20), high titratable acidity, up to $100 \mathrm{meq} \cdot \mathrm{L}^{-1}$ of tartaric acid, and soluble sugar content ranging from $16^{\circ}$ to $19^{\circ}$ Brix, in order to have a fresh beverage with final alcohol content between 9 and 10\%. Therefore, grapes must be harvested before reaching full maturity, which will ensure the acidity and alcoholic content (Rizzon et al. 2009; Mendonça et al. 2016). Lower berry temperatures contribute to maintaining acidity levels (Morrison and Noble 1990).

\section{Base wine composition}

Base wine composition followed standards for sparkling wines production, and they are similar to those found in 'Chardonnay' base wines produced in the southern of Brazil, a traditional sparkling wine producer (Rizzon et al. 2009). In 2016 and 2017, base wine acidity was higher in the control group and lower in the east/west treatment, while alcohol content was higher in the east/west treatment in both seasons, and lower in the control treatment in 2016, following the same trend in 2017. Other parameters had fewer variations between groups (Table 5).

These results agree with Diago et al. (2010), who observed higher sugar and alcohol content in wines from defoliated 'Tempranillo,' 'Graciano' and 'Mazuelo' vines. Baiano et al. (2015) also found that more intense leaf removal at ripening stage resulted in higher alcoholic wines for the Nero di Troia cultivar. However, Tessarin et al. (2014) suggest defoliation at veraison to reduce sugar concentration of berries and reduce alcohol content of red wines, as reducing leaf area it would affect carbohydrates reserve for fruit development during ripening, opposing the results of this study.

\section{Volatile compounds}

Thirty-four volatile compounds were identified in 'Chardonnay' base wine, including 2 aliphatic acids, 4 aliphatic alcohols, 1 aliphatic aldehyde, 15 aliphatic esters, 1 aliphatic ketone, 5 benzenoids, 4 branched esters, 1 cyclic ketone and 2 monoterpenoids (Table 6).

Base wines characterization was based on multivariate statistical analysis. Principal component analysis was applied to verify which trends or groups of wine samples occurred according to the aromatic composition by chemical classes. 
Table 5. Total Acidity $(\mathrm{TA}), \mathrm{pH}$, dry extract $\left(\mathrm{g} \cdot \mathrm{L}^{-1}\right)$, residual sugars $\left(\mathrm{g} \cdot \mathrm{L}^{-1}\right)$, alcohol $(\%)$ in 'Chardonnay' base wine submitted to different late defoliation orientation, 2016 and 2017 seasons.

\begin{tabular}{|c|c|c|c|c|}
\hline \multirow{3}{*}{ Harvest Year } & \multicolumn{4}{|c|}{ DEFOLIATION } \\
\hline & Control & East & West & East/West \\
\hline & \multicolumn{4}{|c|}{ TA (meq $\left.\cdot \mathrm{L}^{-1}\right)$} \\
\hline 2016 & $148.33 d$ & $135.33 b$ & $140.33 c$ & $132.67 a$ \\
\hline \multirow[t]{2}{*}{2017} & $147.67 \mathrm{~d}$ & $140.67 b$ & $145.33 \mathrm{c}$ & $132.00 \mathrm{a}$ \\
\hline & \multicolumn{4}{|c|}{$\mathrm{pH}$} \\
\hline 2016 & $3.11 \mathrm{a}$ & $3.12 \mathrm{a}$ & $3.12 \mathrm{a}$ & $3.15 b$ \\
\hline \multirow[t]{2}{*}{2017} & $3.20 \mathrm{c}$ & $3.17 b$ & $3.15 \mathrm{a}$ & $3.20 \mathrm{c}$ \\
\hline & \multicolumn{4}{|c|}{ Dry Extract $\left(g \cdot \mathrm{L}^{-1}\right)$} \\
\hline 2016 & $23.63 a$ & $23.17 \mathrm{a}$ & $23.67 a$ & $23.37 a$ \\
\hline \multirow[t]{2}{*}{2017} & $25.07 \mathrm{~b}$ & $25.10 \mathrm{a}$ & $25.17 a$ & $24.43 b$ \\
\hline & \multicolumn{4}{|c|}{ Residual Sugars $\left(\mathrm{g} \cdot \mathrm{L}^{-1}\right)$} \\
\hline 2016 & $0.86 a$ & $0.93 a$ & $1.06 \mathrm{a}$ & $0.93 a$ \\
\hline \multirow[t]{2}{*}{2017} & $1.33 \mathrm{~b}$ & $1.73 \mathrm{a}$ & $1.59 \mathrm{a}$ & $1.53 \mathrm{a}$ \\
\hline & \multicolumn{4}{|c|}{ Alcohol (\%) } \\
\hline 2016 & $10.53 \mathrm{a}$ & $10.95 \mathrm{c}$ & $10.63 \mathrm{~b}$ & $11.13 \mathrm{~d}$ \\
\hline 2017 & $9.47 a$ & $9.81 b$ & $9.44 \mathrm{a}$ & $10.29 c$ \\
\hline
\end{tabular}

Averages followed by same letter in same column were not significantly different at $5 \%$ of probability by Scott-Knott test.

Regarding the comparison between harvests, component 1 explained $45.4 \%$ and component 2, 24.6\% variation between 2016 and 2017 seasons (Fig. 4).

The 2016 vintage was negatively carried to the left quadrant, with the exception of the east/west treatment, while the 2017 vintage was positively carried and grouped in the right quadrant with most aromatic classes. Both years remained close to the center indicating the presence of the same aromatic classes, but with higher concentration in the 2017 vintage, evidencing that the aromatic composition were influenced by the highest berry temperatures observed in this vintage. Studies show that climatic conditions influence aromas biosynthesis in the grapes, increasing or decreasing its concentration according to stresses suffered by the plants, and consequently this is reflected in wine (Hernandez-Orte et al. 2015; Alessandrini et al. 2017). High fruit temperatures also modify biosynthesis of aroma precursors (Šuklje et al. 2014).

Principal component analysis in 2016 explained $78.5 \%$ of variation between the different base wines, and the component 1 accounted for more than $60 \%$ (Fig. 5).

Aliphatic alcohol and aliphatic aldehyde were correlated and negatively carried with aliphatic acid, aliphatic ester, aliphatic ketone, benzenoids and branched ester, which were highly correlated with each other. The presence and absence of aromatic classes separated the treatments into four different groups in the graph: West treatment was highlighted by the presence of cyclic ketone and east treatment by the presence of monoterpenes, both characterized by floral notes. East/west treatment differed from the others by absence of aliphatic alcohol and aliphatic aldehyde, explained by the higher sun exposure and higher temperatures.

In the principal component analysis in 2017 , the component 1 explained $43.2 \%$ and the component $2,25.7 \%$ of variation between the different groups (Fig. 6).

The control group showed a tendency to higher concentrations of benzenoids and aliphatic aldehyde, characterized by floral notes. Defoliated treatments resulted in base wines with higher aliphatic ketone, aliphatic esters and monoterpenoids concentrations, giving fruity, tropical and floral notes.

Leaf removal increases monoterpenes and other potentially volatile terpenes in 'Sauvignon Blanc', 'Gewürztraminer' and 'Chardonnay Musqué' grapes, resulting in wines with higher citrus, tropical and floral aromas and flavors than 
Table 6. Volatile compounds identified in ‘Chardonnay’ base wine using GC-MS extracted by DVB/CAR/PDMS, 2016 and 2017 seasons.

\begin{tabular}{|c|c|c|c|}
\hline Volatile compounds & CAS\# & $\mathrm{KI}^{\mathrm{a}}$ & Aromatic notes \\
\hline \multicolumn{4}{|c|}{ Aliphatic acids } \\
\hline Hexanoic acid & $000142-62-1$ & 998 & Rancid; Blue cheese \\
\hline n-Decanoic acid & $000334-48-5$ & 1373 & Rancid \\
\hline \multicolumn{4}{|c|}{ Aliphatic alcohols } \\
\hline 1-Hexanol & $000111-27-3$ & 851 & Herbaceous; Green fruit \\
\hline 1-Heptanol & $000111-70-6$ & 962 & Herbaceous \\
\hline 1-Octanol & $000111-87-5$ & 1072 & Citric; Green \\
\hline 1-Decanol & $000112-30-1$ & 1263 & Orange flower \\
\hline \multicolumn{4}{|c|}{ Aliphatic aldehyde } \\
\hline Nonanal & $000124-19-6$ & 1104 & Floral; Citric \\
\hline \multicolumn{4}{|c|}{ Aliphatic esters } \\
\hline Ethyl butyrate & 000105-54-4 & 804 & Fruity; Pineapple \\
\hline Ethyl heptanoate & 000106-30-9 & 1100 & Fruity; Brandy \\
\hline Ethyl laurate & $000106-33-2$ & 1596 & Floral and Fruity \\
\hline Ethyl decanoate & $000110-38-3$ & 1398 & Grape; Brandy \\
\hline Methyl octanoate & $000111-11-5$ & 1129 & Orange \\
\hline Methyl laurate & $000111-82-0$ & 1509 & Floral \\
\hline Diethyl succinate & $000123-25-1$ & 1167 & Light fruity \\
\hline Ethyl nonanoate & 000123-29-5 & 1298 & Fruity; Brandy \\
\hline Ethyl hexanoate & $000123-66-0$ & 1002 & Pineapple; Banana \\
\hline Ethyl myristate & 000124-06-1 & 1795 & Orris root \\
\hline Hexyl acetate & $000142-92-7$ & 1014 & Pear; Floral \\
\hline Propyl octanoate & $000624-13-5$ & 1294 & Coconut; Yeast \\
\hline n-Propyl hexanoate & 000626-77-7 & 1097 & Pineapple; Blackberry \\
\hline Ethyl undecanoate & $000627-90-7$ & 1496 & Coconut; Brandy \\
\hline Ethyl palmitate & $000628-97-7$ & 1902 & Wax; Sweety \\
\hline \multicolumn{4}{|c|}{ Aliphatic ketone } \\
\hline 2-Nonanone & $000821-55-6$ & 1093 & Rue \\
\hline \multicolumn{4}{|c|}{ Benzenoids } \\
\hline Phenylethyl alcohol & $000060-12-8$ & 1118 & Rose \\
\hline Styrene & $000100-42-5$ & 893 & Balsamic; Floral \\
\hline Benzaldehyde & $000100-52-7$ & 962 & Toasted; Malt \\
\hline Phenethyl acetate & $000103-45-7$ & 1260 & Floral; Honey \\
\hline Phenylacetaldehyde & $000122-78-1$ & 1049 & Hyacinth; Honey \\
\hline \multicolumn{4}{|c|}{ Branched esters } \\
\hline Isoamyl acetate & $000123-92-2$ & 876 & Banana \\
\hline 2-Methylbutyl acetate & $000624-41-9$ & 886 & Banana; Apple \\
\hline Isoamyl octanoate & 002035-99-6 & 1450 & Fruity \\
\hline Isoamyl hexanoate & 002198-61-0 & 1254 & Fruity; Anise \\
\hline \multicolumn{4}{|c|}{ Cyclic ketone } \\
\hline (E)- $\beta$-damascenone & 023696-85-7 & 1386 & Floral \\
\hline \multicolumn{4}{|c|}{ Nonoterpenoids } \\
\hline Citronellol & $000106-22-9$ & 1232 & Floral; Citric \\
\hline 6-Octen-1-ol, 3,7-dimethyl-, (R)- & 001117-61-9 & 1232 & Floral; Rose \\
\hline
\end{tabular}

${ }^{a}$ Confirmed by comparison with Kovats Index on DB5 Column (Adams et al. 2007). 
wines from vines without leaf removal (Reynolds et al. 2007). Defoliation is also associated with fruitier/more tropical and floral drink perception. Most aroma precursors synthesis occur at higher temperatures and in sun-exposed grapes (Hernandez-Orte et al. 2015). On the other hand, wines from vines without leaf removal have a sensory profile with more intense herbaceous notes and higher acidity (Šuklje et al. 2014). Alessandrini et al. (2017) found a significant reduction in aliphatic alcohols in Semillon berries from defoliated plants, for example, when compared to berries from nondefoliated vines.

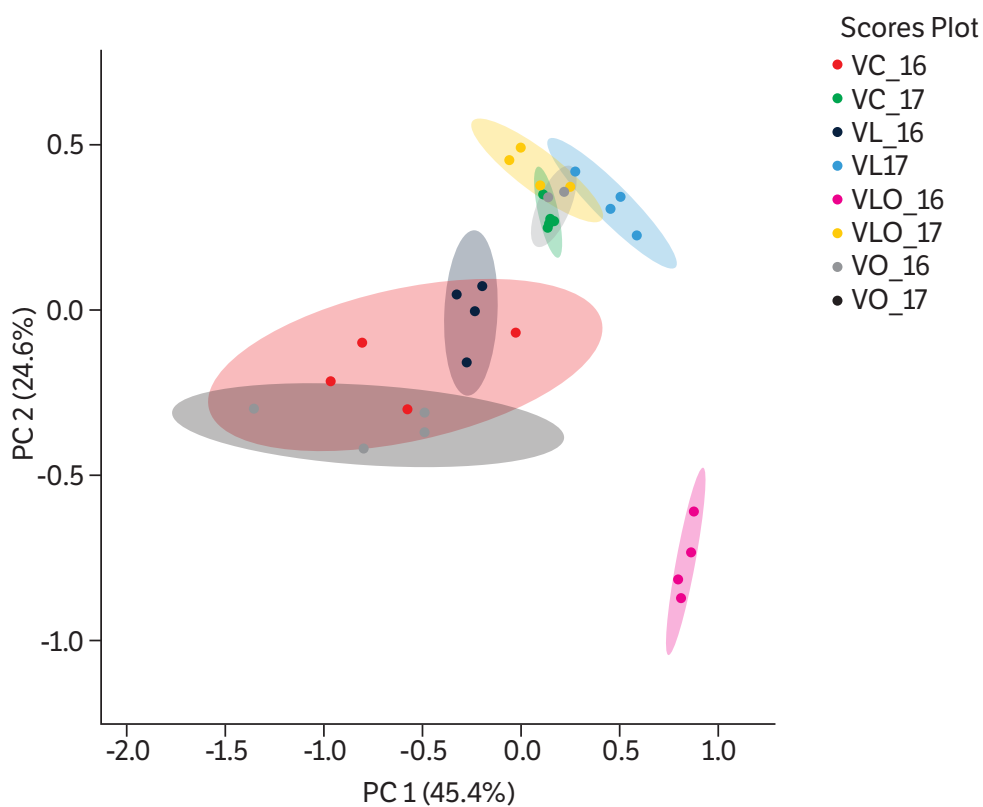

Each data represents Each data represents the average of four replicates per treatment. (VC: control without defoliation; VL: east defoliation; VO: west defoliation; VLO: east/ west defoliation).

Figure 4. Principal component analysis of the aromatic composition of 'Chardonnay' base wines submitted to different late defoliation orientation in 2016 and 2017 seasons.
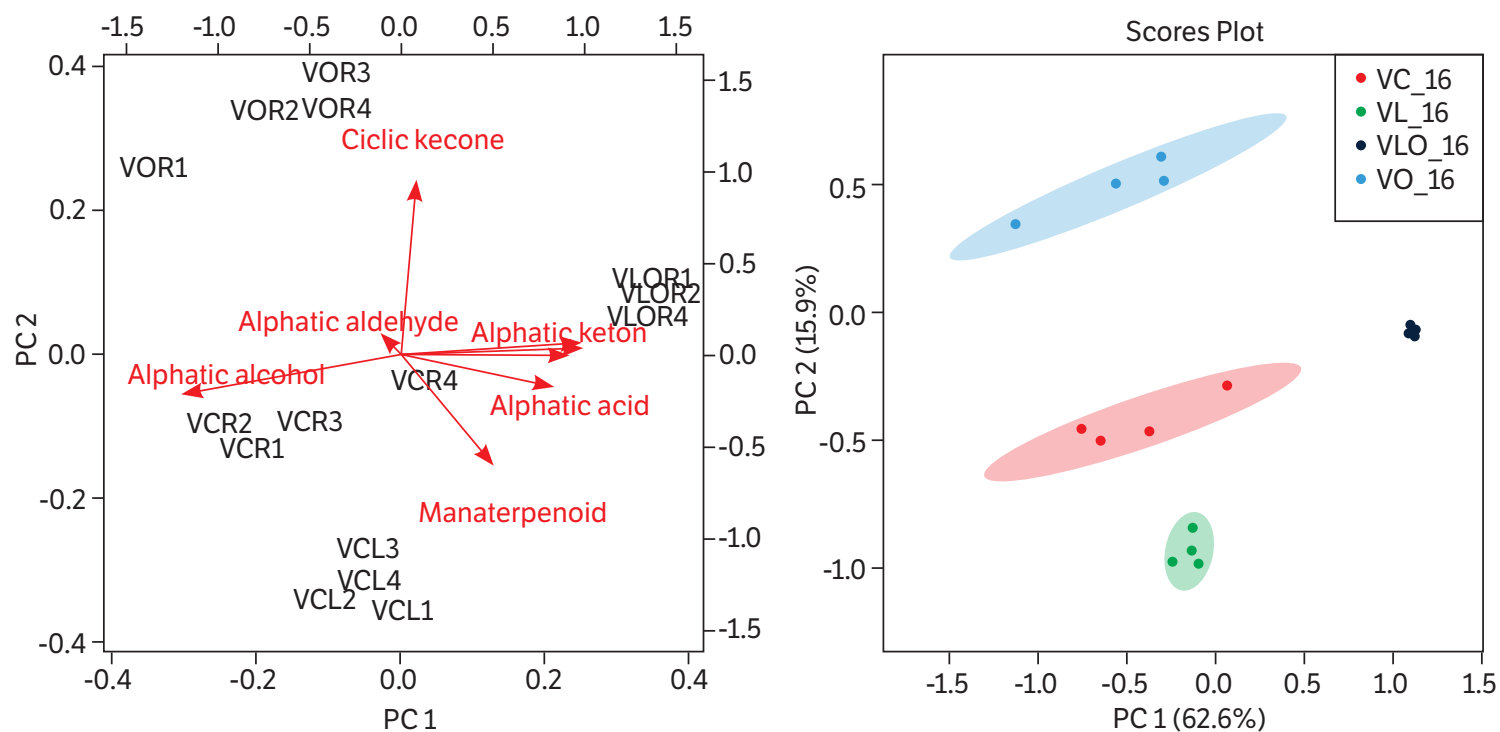

Legend: Each data represents the average of four replicates per treatment. VC: control without defoliation; VL: east defoliation; VO: west defoliation; VLO: east/ west defoliation.

Figure 5. Principal component analysis of the aromatic composition of 'Chardonnay' base wines submitted to different late defoliation orientation in 2016. 

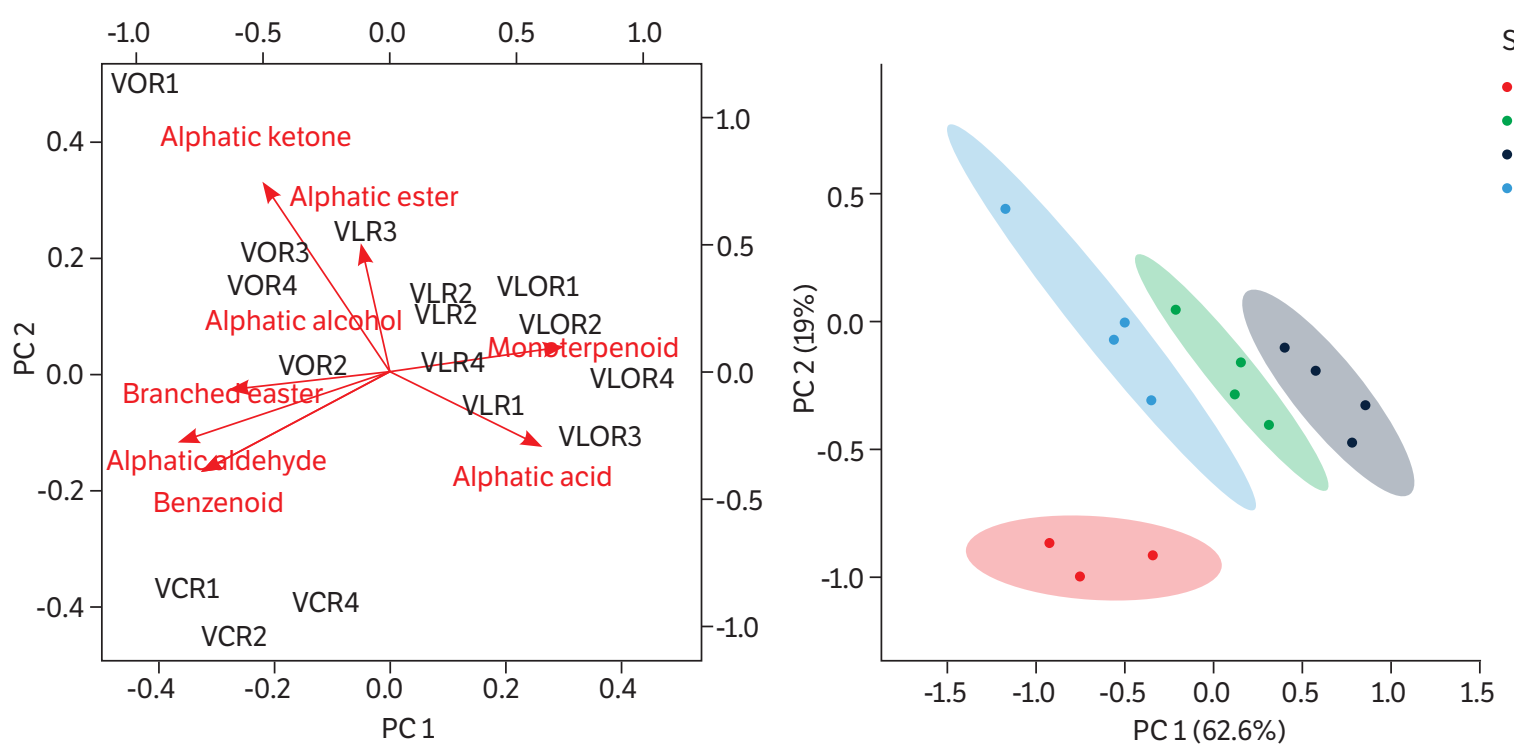

Scores Plot

- VC_16

- VL_16

- VLO 16

- VO_ 16

Each data represents the average of four replicates per treatment. VC: control without defoliation; VL: east defoliation; VO: west defoliation; VLO: east/ west defoliation.

Figure 6. Principal component analysis of the aromatic composition of 'Chardonnay' base wines submitted to different late defoliation orientation in 2016.

\section{CONCLUSION}

The more intense defoliation (east/west) reduced the must and base wine total acidity, and increased the must and wine soluble solids and alcohol content, respectively. Late defoliation was also associated with a higher incidence of Glomerella cingulata. Defoliation did not affect vines yield, but modified the aromatic profile of base wines, favoring fruity, citrus and tropical notes.

Late defoliation is not indicated for regions characterized by subtropical highland climate (Cwb) of Southeastern Brazil.

\section{AUTHORS' CONTRIBUTION}

Conceptualization, Figueiredo G. M. and Mota R. V.; Methodology, Figueiredo G. M.; Souza C. R.; Mota R. V; Peregrino I.; Investigation, Figueiredo G. M. and Fernandes F. P.; Writing - Original Draft, Figueiredo G. M. and Regina M. A.; Writing - Review and Editing, Figueiredo G. M.; Funding Acquisition, Souza C. R. and Mota R. V.; Resources, Peregrino I. and Regina M. A.; Supervision, Figueiredo G. M.

\section{REFERENCES}

Adams, R. P. (2007). Identification of essential oil components by gas chromatography/mass spectrometry. Vol. 456. Carol Stream: Allured publishing corporation.

Alessandrini, M., Battista, F., Panighel, A., Flamini, R. and Tomasi, D. (2017). Effect of pre-bloom leaf removal on grape aroma composition and wine sensory profile of Semillon cultivar. Journal of the Science of Food and Agriculture, 98, 1674-1684. https:// doi.org/10.1002/jsfa.8638

Amerine, M. A. and Ough, C. S. (1980). Methods for Analysis of Musts and Wines. New York: John Wiley. 
Baiano, A., De Gianni, A., Previtali, M. A., Del Nobile, M. A., Novello, V. and de Palma, L. (2015). Effects of defoliation on quality attributes of Nero di Troia (Vitis vinifera L.) grape and wine. Food Research International, 75, 260-269. https://doi.org/10.1016/j.foodres.2015.06.007

Burdock, G. A. (2010). Fenaroli's handbook of flavor ingredients. Boca Raton: CRC press.

Diago, M. P., Vilanova, M. and Tardaguila, J. (2010). Effects of timing of manual and mechanical early defoliation on the aroma of Vitis vinifera L. Tempranillo wine. American Journal of Enology and Viticulture, 61, 382-391.

[EMBRAPA] Empresa Brasileira de Pesquisa Agropecuária (s.d.). Descritores Minimos para Avaliação de Cultivares de Videira. Bento Gonçalves: CNPUV. (Documento de circulação restrita).

Ettre, L. S. (2003). Retention index expressions. Chromatographia, 58, 491-494. https://doi.org/10.1365/s10337-003-0075-x

Gürbüz, O., Rouseff, J. M. and Rouseff, R. L. (2006). Comparison of aroma volatiles in commercial Merlot and Cabernet Sauvignon wines using gas chromatography- olfactometry and gas chromatography- mass spectrometry. Journal of Agricultural and Food Chemistry, 54, 3990-3996. https://doi.org/10.1021/jf053278p

Hed, B., Ngugi, H. K. and Travis, J. W. (2015). Short-and long-term effects of leaf removal and gibberellin on Chardonnay grapes in the Lake Erie region of Pennsylvania. American Journal of Enology and Viticulture, 66, 22-29. https://doi.org/10.5344/ajev.2014.14034

Hernandez-Orte, P., Concejero, B., Astrain, J., Lacau, B., Cacho, J. and Ferreira, V. (2015). Influence of viticulture practices on grape aroma precursors and their relation with wine aroma. Journal of the Science of Food and Agriculture, 95, 688-701. https://doi. org/10.1002/jsfa.6748

Ilc, T., Werck-Reichhart, D. and Navrot, N. (2016). Meta-analysis of the core aroma components of grape and wine aroma. Frontiers in Plant Science, 7, 1-15. https://doi.org/10.3389/fpls.2016.01472

Jackson, R. S. (2008). Wine science: principles and applications. London: Academic press.

Leão, P. C. S., Nunes, B. T. G. and Lima, M. A. C. (2016). Canopy management effects on 'Syrah' grapevines under tropical semi-arid conditions. Scientia Agricola, 73, 209-216. https://doi.org/10.1590/0103-9016-2014-0408

Lee, J. and Skinkis, P. A. (2013). Oregon 'Pinot noir'grape anthocyanin enhancement by early leaf removal. Food Chemistry, 139, 893901. https://doi.org/10.1016/j.foodchem.2013.02.022

Manfroi, V., Miele, A., Rizzon, L. A., Barradas, C. I. N. and Manfroi, L. (1997). Effect of different defoliation and harvesting times in the composition of Cabernet Sauvignon wine. Ciência Rural, 27, 139-143. https://doi.org/10.1590/S0103-84781997000100024

McClellan, W. D. and Hewitt, W. B. (1973). Early Botrytis rot of grapes: Time of infection and latency of Botrytis cinerea Pers. in Vitis vinifera L. Phytopathology, 63, 1151-1157. https://doi.org/10.1094/Phyto-63-1151

Mendonça, T. R., Mota, R. V., Souza, C. R., Dias, F. A. N., Pimentel, R. M. A. and Regina, M. A. (2016). Pruning management of Chardonnay grapevines at high altitude in Brazilian southeast. Bragantia, 75, 57-62. https://doi.org/10.1590/1678-4499.243

Morrison, J. C. and Noble, A. C. (1990). The effects of leaf and cluster shading on the composition of Cabernet Sauvignon grapes and on fruit and wine sensory properties. American Journal of Enology and Viticulture, 41, 193-200.

Pötter, G. H., Daudt, C. E., Brackamnn, A., Leite, T. T, and Penna, N. G. (2010). Desfolha parcial em videiras e seus efeitos em uvas e vinhos Cabernet Sauvignon da região da Campanha do Rio Grande do Sul, Brasil. Ciência Rural, 40, 2011-2016. https://doi.org/10.1590/ S0103-84782010000900025

Reynolds, A. G., Schlosser, J., Power, R., Roberts, R., Willwerth, J. and De Savigny, C. (2007). Magnitude and interaction of viticultural and enological effects. I. Impact of canopy management and yeast strain on sensory and chemical composition of Chardonnay Musqué. American Journal of Enology and Viticulture, 58, 12-24. 
Rizzon, L. A., Miele, A. and Scopel, G. (2009). Analytical characteristcs of Chardonnay wines from the Serra Gaúcha region. Ciência Rural, 39, 2555-2558. https://doi.org/10.1590/S0103-84782009005000174

Steel, C. C., Greer, L. A., Savocchia, S. and Samuelian, S. K. (2011). Effect of temperature on Botrytis cinerea, Colletotrichum acutatum and Greeneria uvicola mixed fungal infection of Vitis vinifera grape berries. Vitis, 50, 69-71.

Šuklje, K., Antalick, G., Coetzee, Z., Schmidtke, L. M., Baša Česnik, H., Brandt, J. du Toit, W. J., Lisjak K. and Deloire, A. (2014). Effect of leaf removal and ultraviolet radiation on the composition and sensory perception of Vitis vinifera L. cv. Sauvignon Blanc wine. Australian Journal of Grape and Wine Research, 20, 223-233. https://doi.org/10.1111/ajgw.12083

Tessarin, P., Boliani, A. C., Botelho, R. V., Rusin, C., Versari, A., Parpinello, G. P. and Rombolà, A. D. (2014). Effects of late defoliations on chemical and sensory characteristics of cv. uva longanesi wines. Journal of Soil Science and Plant Nutrition, 14, 1021-1038. https://doi. org/10.4067/S0718-95162014005000079

Thomas, C. S., Marois, J. J. and English, J. T. (1988). The effects of wind speed, temperature, and relative humidity on development of aerial mycelium and conidia of Botrytis cinerea on grape. Phytopathology, 78, 260-265.

Van Leeuwen, C., Friant, P., Chone, X., Tregoat, O., Koundouras, S. and Dubourdieu, D. (2004). Influence of climate, soil, and cultivar on terroir. American Journal of Enology and Viticulture, 55, 207-217.

Würz, D. A., Brighenti, A. F., Allebrandt, R., Marcon Filho, J. L., Bem, B. P., Araújo Filho, J. V., Rufato, L. and Kretzschmar, A. A. (2017). Early leaf removal as a strategy to control Botrytis cinereal rot in Cabernet Sauvignon grapevine at high altitude regions. Summa Phytopathologica, 43, 111-117. https://doi.org/10.1590/0100-5405/169870

Xia, J., Sinelnikov, I. V., Han, B. and Wishart, D. S. (2015). MetaboAnalyst 3.0 - making metabolomics more meaningful. Nucleic Acids Research, 43, W1, W251-W257. https://doi.org/10.1093/nar/gkv380

Zoecklein, B. W., Wolf, T. K., Duncan, N. W., Judge, J. M. and Cook, M. K. (1992). Effects of fruit zone leaf removal on yield, fruit composition, and fruit rot incidence of Chardonnay and White Riesling (Vitis vinifera L.) grapes. American Journal of Enology and Viticulture, 43, 139-148. 